\title{
Effect of freezing on seaweed photosynthesis
}

\author{
Ian R. Davison, Steve R. Dudgeon, Hang-Ming Ruan
}

Department of Botany and Center for Marine Studies University of Maine, Orono, Maine 04469, USA

\begin{abstract}
The effect of freezing on photosynthesis was studied in a variety of brown and red seaweeds from the Gulf of Maine. USA. Photosynthesis in sublittoral fringe and rock pool species was adversely affected by a single 6 or $12 \mathrm{~h}$ exposure to $-20^{\circ} \mathrm{C}$ even after a $7 \mathrm{~d}$ recovery period in sea water at $5^{\circ} \mathrm{C}$, whereas most intertidal forms were unaffected by this treatment. Three $\mathrm{h}$ at $-20^{\circ} \mathrm{C}$ resulted in an immediate reduction in photosynthesis of most intertidal seaweeds, with the degree of inhibition corresponding to zonation on the shore. For example, photosynthesis in the upper shore fucoid Fucus spiralis was unaffected by $3 \mathrm{~h}$ at $-20^{\circ} \mathrm{C}$, whereas that of the low-intertidal Fucus edentatus was reduced by $97 \%$. The percentage of frozen tissue water after $3 \mathrm{~h}$ at $-20^{\circ} \mathrm{C}$ was similar in all species, suggesting that differences in susceptibility to freezing are attributable to physiological tolerance rather than avoidance. Freezing intolerant species exhibited massive amino acid release on re-immersion in sea water following freezing. In contrast, amino acid release was much lower in freezing tolerant species. The release of amino acids is believed to be due to loss of plasmalemma integrity, suggesting that the freezing tolerance of seaweeds may be controlled by the plasmalemma. Overall, the results of this study suggest that freezing may play an important role in structuring sub-arctic and boreal intertidal communities. Freezing can operate in 2 ways: (1) as a disturbance excluding sub-littoral and rock pool species from the eulittoral and (2) as a physiological stress affecting relative competitive abilities of eulittoral forms via differential reduction in photosynthesis and hence growth.
\end{abstract}

\section{INTRODUCTION}

Rocky intertidal sea shores typically exhibit a pronounced vertical zonation of animals and plants (Lewis 1964). Zaneveld (1969) and Connell (1972) proposed that upper distribution limits are determined primarily by physical factors, whereas lower limits are controlled by biological interactions. This hypothesis has been widely accepted, despite being inconsistent with results of several more recent studies (see Chapman 1986). Although gradients in physiological tolerance to physical factors are frequently correlated with observed distribution patterns (e.g. Schonbeck \& Norton 1978, Dring \& Brown 1982), this does not demonstrate per se that physical factors set upper distribution limits. This was emphasized by a classic series of studies by Schonbeck \& Norton $(1978,1979$ a, b, 1980a, b) which suggested that upper limits correspond to the fundamental niche (sensu Hutchinson 1957), set by desiccation tolerance, in some fucoids (Pelvetia canaliculata and Fucus spiralis) but not in others ( $F$. vesiculosus and $F$. serratus).

Irrespective of the exact role of physical factors in controlling observed zonation patterns, it is clear that they do have a major influence on the ecology of intertidal seaweeds. To date, most studies have focused on the role of desiccation which is believed to be the most important physical factor affecting intertidal algae (Zaneveld 1969, Hodgson 1980, Lubchenco 1980). Freezing is potentially another important environmental factor in the intertidal zone at high latitudes, where plants may be exposed to several months of subzero minimum temperatures (Parker 1960, Bird \& McLachlan 1974) and in extreme cases be frozen in ice for several months (Kanwisher 1957).

Although the effect of freezing on seaweeds has received relatively little attention, several facts have been established: first, there is a general correlation between freezing tolerance and latitude (Biebl 1970, 1972); second, intertidal forms are more tolerant of freezing than sublittoral or rock pool species (Biebl 1972, Frazer et al. 1988); and third, there is a distinct seasonality in freezing tolerance, suggesting phenotypic acclimation (Parker 1960, Bird \& McLachlan 1974). However, information is lacking in several important areas. One key question concerns the possibility that eulittoral seaweeds exhibit a vertical gradient of freezing tolerance analogous to that established for drought tolerance (Dring \& Brown 1982). Recent studies have suggested that such a gradient may exist, with upper shore forms being more resistant than species from the lower-eulittoral (Frazer et al. 
1988, Dudgeon et al. 1989). However, more research is necessary to establish the generality of this relationship since both studies are based upon data for a single lower-eulittoral species (Frazer et al. 1988, Dudgeon et al. 1989).

Information is also required on the role of freezing as a stress (sensu Grime 1979). Previous research has focused on lethal effects of freezing, i.e. freezing as a disturbance (sensu Grime 1979). Stress is potentially important because it may influence competitive abilities of species (Wilson \& Keddy 1986). Although freezing is known to have a profound impact on photosynthetic metabolism in higher plants (Oquist 1983, Strand \& Oquist 1985, Bauer \& Kofler 1987, Delucia 1987), little is known about the effects on seaweed photosynthesis. Recently, we have established that sublethal freezing exposure has different effects on primary productivity of the red algae Chondrus crispus and Mastocarpus stellatus suggesting that freezing may influence competitive interactions between these species (Dudgeon et al. 1989). Finally, little is known about the mechanisms responsible for freezing tolerance, e.g. why are some seaweeds killed by a single exposure to sub-zero temperatures, whereas others survive repeated freeze/thaw cycles?

This paper describes a study of freezing tolerance in several common perennial intertidal seaweeds of the NW Atlantic. The objectives of the study were to address the 3 questions outlined above, namely: (1) do intertidal seaweeds exhibit a vertical gradient of freezing tolerance; (2) is freezing potentially a sub-lethal stress; and (3) what mechanisms confer freezing tolerance? These questions were addressed by studying the effect of freezing on photosynthesis, a key aspect of metabolism, which is positively correlated with growth (e.g. Davison \& Davison 1987. Hanisak et al. 1988).

\section{MATERIALS AND METHODS}

Plant material. Plants were collected by hand from the shore at Long Cove Point, Chamberlain, Maine, USA, $\left(43^{\circ} 56^{\prime} \mathrm{N}, 69^{\circ} 54^{\prime} \mathrm{W}\right)$ between March and September 1988. Species identified after South \& Hooper (1980) and used in experiments are listed in Table 1.

Plants were transported to the laboratory in sea water, cleaned of visible epibionts and maintained at $5^{\circ} \mathrm{C}$ in plexiglass aquaria containing $6 \mathrm{l}$ of aerated GF/C (Whatman) filtered Provasoli (1968) enriched sea water (PES). The photon flux density (PFD) was 70 to $80 \mu \mathrm{mol}$ photons $\mathrm{m}^{-2} \mathrm{~s}^{-1}$ in a $16: 8 \mathrm{~h} \mathrm{~L}: \mathrm{D}$ cycle. The PES was changed every 4 to $5 \mathrm{~d}$. Plants were used in experiments within $14 \mathrm{~d}$ of their collection from the shore.

Experimental treatments. Plants were exposed to 3 treatments: air at $5{ }^{\circ} \mathrm{C}$, air at $-20{ }^{\circ} \mathrm{C}$ and sea water at $5{ }^{\circ} \mathrm{C}$. All treatments were performed in darkness in closed plexiglass boxes. In long term experiments, plants were returned to the conditions described above (PES, $5{ }^{\circ} \mathrm{C}, 70$ to $80 \mu \mathrm{mol}$ photons $\mathrm{m}^{-2} \mathrm{~s}^{-1}$ ) between freezing treatments. Intact small plants were used in long term experiments, with sections being excised immediately prior to making measurements of photosynthesis and respiration. Short term experiments were performed on excised sections of tissue.

Photosynthetic measurements. Photosynthesis was measured using a Clark type oxygen electrode (Rank Bros, Botisham, UK) at saturating PFD $(500 \mu \mathrm{mol}$ photons $\mathrm{m}^{-2} \mathrm{~s}^{-1}$ ) in $5 \mathrm{ml}$ of $15^{\circ} \mathrm{C}$ sea water. This temperature was selected because it supports high (easily measurable) rates of photosynthesis in all experimental species. Although $15{ }^{\circ} \mathrm{C}$ is above the normal winter sea water temperature at Long Cove Point $\left(0\right.$ to $\left.5^{\circ} \mathrm{C}\right)$, the magnitude of experimental tem-

Table 1 Species used in experiments and location on shore

\begin{tabular}{|c|c|c|}
\hline Algae & Species & Location \\
\hline Brown & $\begin{array}{l}\text { Chordaria flagelliformis (O. F. Mueller) C. Agardh } \\
\text { Laminaria digitata (Huds.) Lamour. } \\
\text { Alaria esculenta (L.) Grev. } \\
\text { Ascophyllun nodosum (L.) Le Jol. } \\
\text { Fucus distichus spp. distichus L. } \\
\text { Fucus distic hus spp. edentatus (de la Pylaie) Powell } \\
\text { Fucus spiralis L. } \\
\text { Fucus vesiculosus L. }\end{array}$ & $\begin{array}{l}\text { Sub-littoral frnge, } \\
\text { rock pools } \\
\text { Sub-littoral fringe. } \\
\text { rock pools } \\
\text { Sub-littoral fringe } \\
\text { Upper-eulittoral } \\
\text { Rock pools } \\
\text { Lower-eulittoral } \\
\text { Upper-eulittoral } \\
\text { Upper-eulittoral }\end{array}$ \\
\hline Red & $\begin{array}{l}\text { Dumontia incrassata O. F. Mueller } \\
\text { Chondrus crispus Stackhouse } \\
\text { Palmaria palmata (L.) Kuntze } \\
\text { Mastocarpus stellatus (Stackhouse in With.) Guiry }\end{array}$ & $\begin{array}{l}\text { Rock pools } \\
\text { Lower-eulittoral } \\
\text { Lower-eulittoral } \\
\text { Upper-eulittoral }\end{array}$ \\
\hline
\end{tabular}


perature difference $\left(35^{\circ} \mathrm{C}:-20^{\circ} \mathrm{C}\right.$ to $\left.15^{\circ} \mathrm{C}\right)$ is within the range expected at this site. The output of the electrode was recorded on a chart recorder connected to a Bailey Instruments RC-1 zero suppressor. This increased the sensitivity of the measurements by allowing the output of the electrode (ca $10 \mathrm{mV}$ full scale) to be recorded on a chart recorder set at $1 \mathrm{mV}$ full scale deflection. The light source was a tungsten-halide lamp in a Kodak slide projector, attenuated with Schott neutral density filters. In all species except Alaria esculenta, Laminaria digitata and Palmaria palmatra 1 to $1.5 \mathrm{~cm}$ long apical sections of the thallus were used for respiration/photosynthesis measurements. In $A$. esculata, L. digitata and $P$. palmata, disks ( $1 \mathrm{~cm}$ diam.) were punched out of the blade with a cork borer. In experiments on the short term effect of freezing on photosynthesis measurements were made 5 min after re-immersing plants in sea water. In other experiments measurements were continued until a stable rate of respiration or photosynthesis was achieved (usually within 5 to $10 \mathrm{~min}$ ).

Amino acid release. Damage to the plasmalemma was assessed by measuring the efflux of amino acids as described previously (Dudgeon et al. 1989). Plant sections for these experiments were cut 12 to $18 \mathrm{~h}$ prior to use, because of loss of amino acids from freshly cut tissue. Total cellular amino acid contents were determined by extracting ca $0.5 \mathrm{~g}$ of tissue twice with hot $80 \%$ ethanol. Amino acids were assayed in the pooled extracts as described by Rosen (1957).

Frozen cellular water. The percentage of frozen cel- lular water in seaweeds was measured by calorimetry as described by Kanwisher $(1955,1957)$.

Statistical analyses. Data on the effect of treatments within a species were analyzed using Student's t-test. Differences in the responses between species and habitats were analyzed by analysis of variance (ANOVA) with multiple comparisons being analyzed by the Student-Newman Keuls (SNK) test. Percentage data were arcsine transformed prior to analysis. ANOVA was performed using the Statistical Analysis System (SAS - version 5.16).

\section{RESULTS}

\section{Long term effect of freezing on photosynthesis and respiration}

Rates of photosynthesis and respiration were measured in a variety of intertidal brown and red algae after a single $12 \mathrm{~h}$ exposure to $-20^{\circ} \mathrm{C}$ followed by a $7 \mathrm{~d}$ recovery period in sea water at $5{ }^{\circ} \mathrm{C}$ (Table 2 ). There were significant differences in the response to freezing depending on habitat (i.e. sub-littoral fringe and rock pool species compared with eulittoral forms) ( $\mathrm{F}=15.87$, $p=0.0004)$. All seaweeds from the sub-littoral fringe and rock pools exhibited significant reduction in photosynthetic rates after a single $12 \mathrm{~h}$ freezing event. The reduction in photosynthesis in species from these habitats ranged from $67 \%$ in Dumontia incrassata to $100 \%$ in Laminaria digitata. In the case of L. digitata

Table 2. The effect of a single $12 \mathrm{~h}$ freezing event on photosynthesis and respiration in a variety of intertidal brown and red macroalgae. Photosynthesis and respiration were measured after a $7 \mathrm{~d}$ recovery period in sea water. Data is expressed in terms of $\mu \mathrm{mol} \mathrm{O} \mathrm{g} \mathrm{fr} \mathrm{wt}^{-1} \mathrm{~h}^{-1}$ Values in parentheses are standard deviation of mean $(\mathrm{n}=3)$. denotes values which differ from controls at 0.05 level (Student's t-test). Letters denote species which exhibited the same percentage change in photosynthesis after $12 \mathrm{~h}$ at $-20^{\circ} \mathrm{C}$ (relative to controls) ( $\mathrm{p}=0.05$, ANOVA)

\begin{tabular}{|c|c|c|c|c|}
\hline \multirow[t]{2}{*}{ Species } & \multicolumn{2}{|c|}{ Photosynthesis } & \multicolumn{2}{|c|}{ Respiration } \\
\hline & Control & $-20^{\circ} \mathrm{C}$ & Control & $-20^{\circ} \mathrm{C}$ \\
\hline \multicolumn{5}{|c|}{ Sub-littoral fringe/Rock pool } \\
\hline Dumontia incrassata & $28.2(2.70)$ & $3.00^{\circ}(4.08)^{\circ}$ & $-8.40(8.58)$ & $-1.20(4.80)$ \\
\hline Chordaria flagelliformis & $22.8(3.66)$ & $4.80^{\circ}(2.70)^{\mathrm{c}}$ & $-8.40(2.70)$ & $-9.60(7.38)$ \\
\hline Laminaria digitata & $17.4(7.02)$ & $0.00^{\cdot}(0.00)^{\mathrm{a}}$ & $-6.60(8.58)$ & $0.00(0.00)$ \\
\hline Fucus distichus & $35.2(10.6)$ & $18.0^{\circ}(5.40)^{\mathrm{a}}$ & $-17.4(2.58)$ & $-15.6(1.14)$ \\
\hline \multicolumn{5}{|l|}{ Lower-eulittoral } \\
\hline Chondrus crispus & $46.2(5.52)$ & $19.2^{\bullet}(8.34)^{a}$ & $-13.2(2.28)$ & $-9.00(2.28)$ \\
\hline Palmaria palmata & $21.0(4.92)$ & $23.4(4.38)^{\mathrm{b}}$ & $-4.80(1.14)$ & $-7.20(1.92)$ \\
\hline Fucus edentatus & $31.8(6.48)$ & $33.0(8.22)^{b}$ & $-9.60(1.26)$ & $-10.8(3.42)$ \\
\hline \multicolumn{5}{|l|}{ Upper-eulittoral } \\
\hline Mastocarpus stellatus & $60.6(14.3)$ & $90.6(41.5)^{b}$ & $-12.0(5.46)$ & $-14.4(2.34)$ \\
\hline Ascophyllum nodosum & $24.6(4.86)$ & $23.4(1.92)^{\mathrm{b}}$ & $-7.80(1.02)$ & $-10.8(3.60)$ \\
\hline Fucus vesiculosus & $31.8(7.86)$ & $41.4(12.1)^{\mathrm{b}}$ & $-7.20(1.62)$ & $-7.20(2.16)$ \\
\hline Fucus spiralis & $34.8(6.24)$ & $35.4(9.54)^{b}$ & $-11.4(2.58)$ & $-12.6(3.66)$ \\
\hline
\end{tabular}


Table 3 . The effect of repeated exposure to freezing on photosynthesis and respiration on several brown and red eulittoral algae Plants were frozen daily for $3 \mathrm{~h}$ at $-20{ }^{\circ} \mathrm{C}$ for $7 \mathrm{~d}$. Data are expressed in $\mu \mathrm{mol} \mathrm{O}_{2} \mathrm{~g}$ fr wt ${ }^{\prime} \mathrm{h}^{-1}$. Values in parentheses are standard deviation of mean $(\mathrm{n}=5)$. ' denotes values which differ significantly from unfrozen controls at 0.05 level (Student's $t$-test). Percentage change in photosynthesis at $-20^{\circ} \mathrm{C}$ (relative to controls) did not differ significantly between species with same letter $(p=0.05$, ANOVA)

\begin{tabular}{|c|c|c|c|c|}
\hline \multirow[t]{2}{*}{ Species } & \multicolumn{2}{|c|}{ Photosynthesis } & \multicolumn{2}{|c|}{ Respiration } \\
\hline & Control & $-20^{\circ} \mathrm{C}$ & Control & $-20^{\circ} \mathrm{C}$ \\
\hline \multicolumn{5}{|l|}{ Lower-eulittoral } \\
\hline Chondrus crispus & $14.9(8.41)$ & $4.24^{\cdot}(4.54)^{d}$ & $-4.50(2.37)$ & $-3.85(3.53)$ \\
\hline Palmaria palmata & $10.5(1.71)$ & $5.98^{\cdot}(2.53)^{\mathrm{ab}}$ & $-3.58(1.29)$ & $-3.15 \quad(1.99)$ \\
\hline Fucus edentatus & $18.8(5.55)$ & $15.5(5.65)^{a b c}$ & $-4.45(2.15)$ & $-5.08 \quad(2.01)$ \\
\hline \multicolumn{5}{|l|}{ Upper-eulittoral } \\
\hline Mastocarpus stellatus & $16.8(7.02)$ & $15.4(5.65)^{\mathrm{bc}}$ & $-7.26(1.62)$ & $-7.75 \quad(2.37)$ \\
\hline Fucus vesiculosus & $11.5(2.79)$ & $13.7(4.83)^{c}$ & $-3.29(0.60)$ & $-3.48 \quad(1.33)$ \\
\hline Fucus spiralis & $11.6(4.62)$ & $13.0(3.02)^{\mathrm{bc}}$ & $-2.70(0.82)$ & $-5.21 \cdot(1.79)$ \\
\hline
\end{tabular}

and Alaria esculenta (data not shown) plants were clearly dead and had disintegrated. A similar pattern was obtained $1 \mathrm{wk}$ after a single $6 \mathrm{~h}$ exposure to $-20^{\circ} \mathrm{C}$ (data not shown). With the exception of Chondrus crispus none of the eulittoral seaweeds exhibited a significant reduction in photosynthesis. Respiration was less affected than photosynthesis even in sub-littoral fringe and rock pool species and there was no significant effect of freezing on respiration in any of the species tested. The differences in control rates of photosynthesis between experiments (e.g. Table $2 \mathrm{cf}$. Table 3) are probably due to differences between batches of plants collected at different times and to different periods of maintenance in laboratory culture.

Subsequent experiments were performed to evaluate the effect of repeated freeze/thaw cycles on the more resistant eulittoral algae. Plants were frozen daily for $3 \mathrm{~h}$ at $-20^{\circ} \mathrm{C}$ for $7 \mathrm{~d}$ but were not frozen on the day that photosynthesis and respiration were measured. Photosynthesis in the 3 eulittoral fucoids (Fucus vesiculosus, $F$. edentatus and F. spiralis) was not adversely affected by daily freezing and the same was true for the uppereulittoral red alga Mastocarpus stellatus (Table 3). However, photosynthesis in the lower-eulittoral red algae Chondrus crispus and Palmaria palmata was significantly reduced by daily freezing (by 70 and $76 \%$ of controls, respectively). As with the single freezing exposure, respiration was not affected by repeated freezing at $-20^{\circ} \mathrm{C}$, except in $F$. spiralis where frozen plants had significantly higher rates of respiration than controls.

\section{Short term effect of freezing on photosynthesis}

Photosynthesis was measured in the freezing susceptible Dumontia incrassata and freezing tolerant
Fucus vesiculosus immediately following a time course emersion at $5{ }^{\circ} \mathrm{C}$ or $-20^{\circ} \mathrm{C}$ (Fig. 1). Rates of photosynthesis were measured 5 min after transferring plant
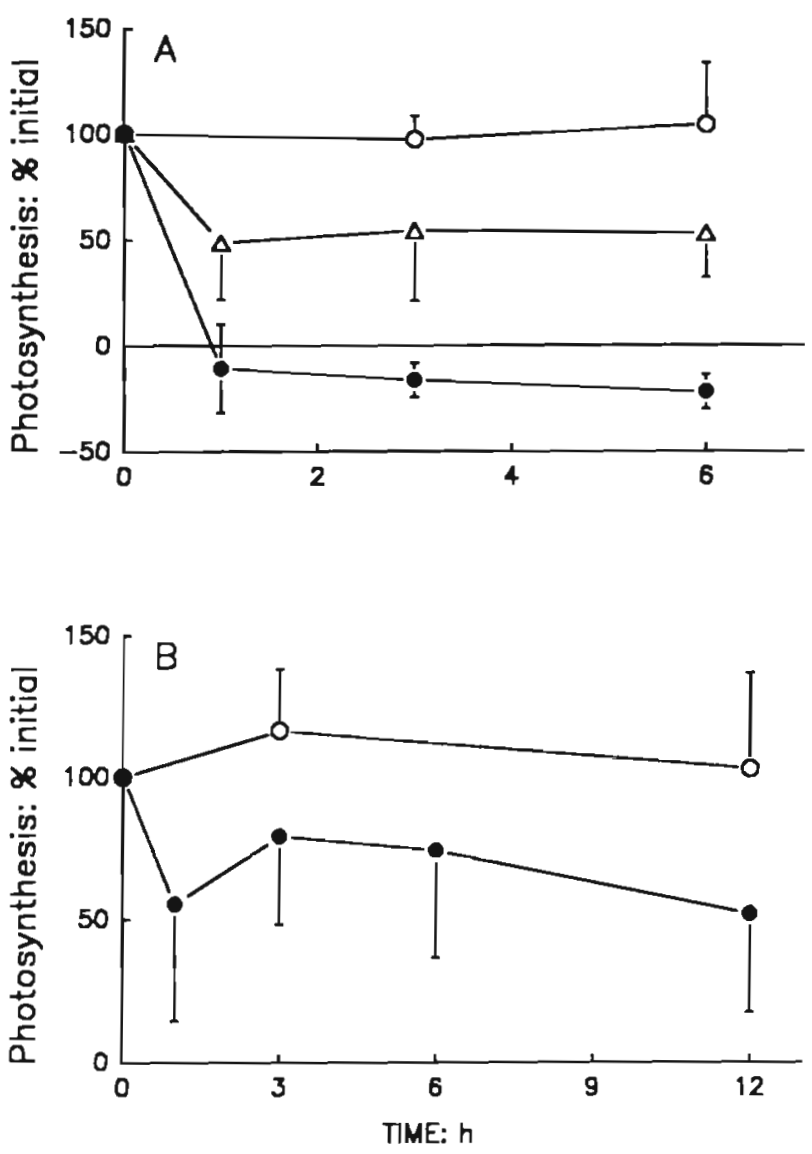

Fig. 1. Time course of photosynthesis in: (A) the red alga Dumontia incrassata and (B) the brown alga Fucus vesiculosus. Plants were: immersed in sea water at $5^{\circ} \mathrm{C}$ jopen circles), emersed in arr at $5^{\circ} \mathrm{C}$ (open triangles) or frozen in air at $-20^{\circ} \mathrm{C}$ (closed circles). Vertical bars denote $95 \%$ confidence limits of mean $(n=4$, Dumontia; $n=4$ Fucus $)$ 
sections from experimental conditions to $15{ }^{\circ} \mathrm{C}$ sea water in the oxygen electrode chamber. Photosynthetic rates of control plants held in sea water at $5{ }^{\circ} \mathrm{C}$ remained constant (relative to initial values) in both species. Photosynthesis in $D$. incrassata declined to $50 \%$ of control values within 1 h at $5{ }^{\circ} \mathrm{C}$, remaining at approximately this level up to $6 \mathrm{~h}$ (Fig. 1A). D. incrassata was incapable of achieving net photosynthesis after $1 \mathrm{~h}$ incubation at $-20{ }^{\circ} \mathrm{C}$. Photosynthesis of $F$. vesiculosus held at $5^{\circ} \mathrm{C}$ in air did not differ significantly from controls (data not shown), whereas photosynthesis in plants held at $-20{ }^{\circ} \mathrm{C}$ declined to $55 \%$ of initial values after $1 \mathrm{~h}$ and did not vary significantly from this value up to $12 \mathrm{~h}$ (Fig. 1B).

All species except Fucus spiralis and Mastocarpus stellatus exhibited significant reductions in photosynthesis after $3 \mathrm{~h}$ at $-20^{\circ} \mathrm{C}$ similar to those shown in Fig. 1 (Table 4). There were significant differences in the response to freezing depending on habitat. When species were grouped according to habitat, sub-littoral fringe and rock pool species were found to be more severely inhibited than eulittoral forms $(F=10.39, p<0.0001)$. None of the species studied exhibited a significant change in photosynthesis after $3 \mathrm{~h}$ in air at $5^{\circ} \mathrm{C}$

\section{Effect of freezing on membrane permeability}

The time course of amino acid release from Dumontia incrassata was monitored following re-immersion in sea water at $15^{\circ} \mathrm{C}$ after $3 \mathrm{~h}$ in air at $5^{\circ} \mathrm{C}$ or $-20^{\circ} \mathrm{C}$ (Fig. 2). Plants emersed at $5^{\circ} \mathrm{C}$ only released a small

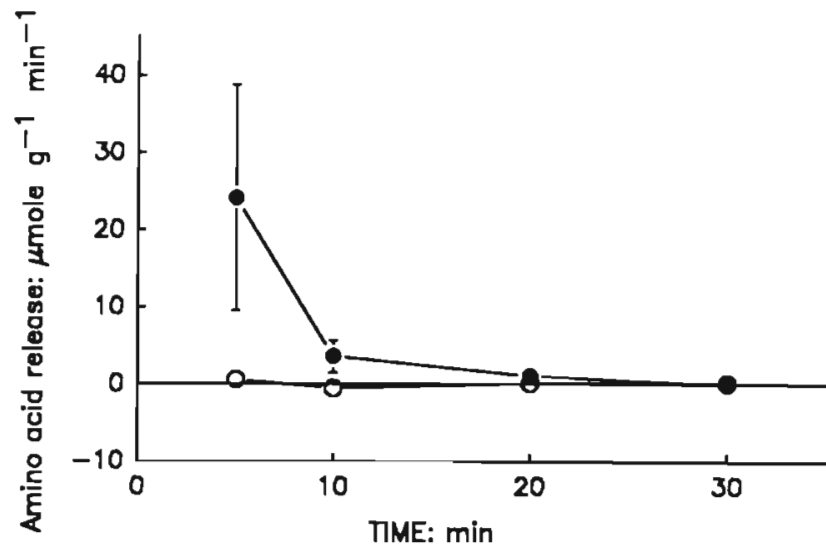

Fig. 2. Time course of amino acid release from the red alga Dumontia incrassata following transfer to $15^{\circ} \mathrm{C}$ sea water after $3 \mathrm{~h}$ in air at $5^{\circ} \mathrm{C}$ (open circles) or $3 \mathrm{~h}$ in air at $-20^{\circ} \mathrm{C}$ (closed circles). Vertical bars denote $95 \%$ confidence limits of mean (n $=5)$

quantity of amino acids, whereas a massive release occurred from plants exposed to $-20^{\circ} \mathrm{C}$. Most amino acid release occurred within 5 min of transferring plants to sea water. The pattern of release shown in Fig. 2 was typical of all species examined, although there was considerable variation in the proportion of the cellular amino acid content lost due to freezing damage to the plasmalemma (Table 5). The percentage of total cellular amino acids lost after $3 \mathrm{~h}$ at $-20^{\circ} \mathrm{C}$ varied between habitats, with sub-littoral fringe and rock pool species releasing significantly more (70 to $100 \%$ loss) than eulittoral forms ( 0 to $50 \%$ loss) ( $\mathrm{F}=$ $199, \mathrm{p}<0.0001)$. The amino acid release measure-

Table 4 . The effect of $3 \mathrm{~h}$ in air at $5^{\circ} \mathrm{C}$ or $-20^{\circ} \mathrm{C}$ on photosynthesis of several intertidal brown and red macroalgae. Photosynthesis was measured immediately after plants were transferred to sea water at $15^{\circ} \mathrm{C}$. Control plants were maintained in sea water at $5^{\circ} \mathrm{C}$. Data are expressed in terms of $u$ mol $\mathrm{O}_{2} \mathrm{~g} \mathrm{fr} \mathrm{wt}^{-1} \mathrm{~h}^{-1}$ Values in parentheses are standard deviation of mean. denotes significant difference from control values at 0.05 level (Student's t-test). Percentage change of photosynthesis at $-20^{\circ} \mathrm{C}$ (relative to controls) did not differ significantly between species with same letters ( $p=0.05$. ANOVA)

\begin{tabular}{|c|c|c|c|c|}
\hline Species & No. & Control & $5^{\circ} \mathrm{C}$ air & $-20^{\circ} \mathrm{C}$ air \\
\hline \multicolumn{5}{|c|}{ Sub-littoral fringe/Rock pool } \\
\hline Dumontia incrassata & 4 & $20.2(3.96)$ & $16.4(8.40)$ & $-3.60^{\circ}(1.74)^{c}$ \\
\hline Chordaria flagelliformis & 4 & $16.3(5.10)$ & $14.5(4.14)$ & $-2.40^{\circ}(1.44)^{c}$ \\
\hline Laminaria digitata & 4 & $6.66(1.68)$ & $7.44(3.30)$ & $-1.20^{\circ}(1.68)^{\mathrm{c}}$ \\
\hline Alaria esculenta & 4 & $24.5(8.76)$ & $31.4(10.9)$ & $-13.8^{\cdot}(16.6)^{c}$ \\
\hline Fucus distichus & 4 & $28.6(8.82)$ & $18.8(3.66)$ & $0.30^{\circ}(1.08)^{c}$ \\
\hline \multicolumn{5}{|l|}{ Lower-eulittoral } \\
\hline Chondrus crispus & 9 & $20.1(10.8)$ & $15.3(5.11)$ & $-3.58^{\cdot}(5.55)^{\mathrm{C}}$ \\
\hline Palmaria palmata & 9 & $12.2(5.10)$ & $14.1(5.81)$ & $-1.10^{\circ}(4.74)^{\mathrm{c}}$ \\
\hline Fucus edentatus & 9 & $21.9(8.48)$ & $27.6(12.0)$ & $0.73^{\circ}(4.12)^{c}$ \\
\hline \multicolumn{5}{|l|}{ Upper-eulittoral } \\
\hline Mastocarpus stellatus & 5 & $8.70(2.77)$ & $7.07(2.17)$ & $6.26(4.08)^{\mathrm{atb}}$ \\
\hline Ascophyllum nodosum & 4 & $12.9(2.22)$ & $12.6(1.95)$ & $6.07^{\cdot}(4.54)^{\mathrm{bc}}$ \\
\hline Fucus vesiculosus & 8 & $18.4(10.1)$ & $17.7(12.3)$ & $8.66^{\circ}(7.76)^{\mathrm{bc}}$ \\
\hline Fucus spiralis & 9 & $14.0(4.55)$ & $12.2(4.97)$ & $14.0(5.21)^{\mathrm{c}}$ \\
\hline
\end{tabular}


Table 5. The effect of $3 \mathrm{~h}$ freezing at $-20^{\circ} \mathrm{C}$ on amino acid release from a variety of brown and red macroalgae. Release is expressed as a percentage of the total cellular amino acid content (umol $\mathrm{g} \mathrm{fr} \mathrm{wt}^{-1}$ ) lost during a 30 min incubation in sea water at $15^{\circ} \mathrm{C}$. Control plants were held in sea water at $5^{\circ} \mathrm{C}$. Values in parentheses are standard deviation of mean (n $=5$ ). . denotes values which differ from control at 0.05 level (Student's test). Percentage release of amino acids at $-20^{\circ} \mathrm{C}$ did not differ significantly between plants with same letters $(p=0.05$, ANOVA)

\begin{tabular}{|c|c|c|c|c|}
\hline \multirow[t]{2}{*}{ Species } & \multirow{2}{*}{$\begin{array}{l}\text { Amino acid } \\
\text { content }\end{array}$} & \multicolumn{3}{|c|}{ Percentage amino acid release } \\
\hline & & Control & \multicolumn{2}{|c|}{$-20^{\circ} \mathrm{C}$} \\
\hline \multicolumn{5}{|c|}{ Sub-littoral fringe/Rock pool } \\
\hline Dumontia incrassata & $120(35.0)$ & $-2.44 \quad(3.52)$ & $100^{\circ}$ & $(39.9)^{a}$ \\
\hline Chordaria flagelliformis & $105(15.5)$ & $2.50 \quad\{0.828\}$ & $74.0^{\circ}$ & $(45.3)^{b}$ \\
\hline Laminaria digitata & $66.5(6.06)$ & $-5.26 \quad(8.26)$ & $73.6^{\circ}$ & $(20.4)^{b}$ \\
\hline Alaria esculenta & $97.9(12.2)$ & $(4.22)$ & $100^{\circ}$ & $(29.9)^{\mathrm{dt}}$ \\
\hline Fucus distichus & $90.6(10.5)$ & $(4.05)$ & $100^{*}$ & $(12.2)^{a}$ \\
\hline \multicolumn{5}{|l|}{ Lower-eulittoral } \\
\hline Chondrus crispus & $160(17.4)$ & $-1.22(0.505)$ & $23.4^{\circ}$ & $(1.51)^{\mathrm{c}}$ \\
\hline Palmaria palmata & $82.5(7.33)$ & $-0.158 \quad(1.59)$ & $47.4^{\circ}$ & $(13.9)^{c}$ \\
\hline Fucus edentatus & $50.6(10.9)$ & $-2.09 \quad(0.860)$ & $6.84^{\circ}$ & $(9.64)^{c d}$ \\
\hline \multicolumn{5}{|l|}{ Upper-eulittoral } \\
\hline Mastocarpus stellatus & $152\{31.4\}$ & $-1.96 \quad(0.815)$ & $2.15^{\circ}$ & $(1.89)^{\alpha}$ \\
\hline Fucus vesiculosus & $4.6 .8(4.59)$ & $-3.12(0.854)$ & $4.58^{\circ}$ & $(3.57)^{\mathrm{cd}}$ \\
\hline Fucus spiralis & $54.8(5.85)$ & $-1.82 \quad(0.527)$ & $-0.321^{\circ}$ & $(0.534)^{d}$ \\
\hline
\end{tabular}

ments may include amino acids released as a result of freezing induced protein hydrolysis. In view of this, we have used the term 'apparent amino acid release' to denote losses of free amino acids plus additional amino acids which may have been produced by protein hydrolysis. This consideration does not preclude the use of apparent amino acid release as a cold stress indicator since free amino acids from the cytoplasm or those produced by proteolysis can only be liberated to the surrounding medium if plasmalemma integrity is lost.

\section{Dehydration and frozen thallus water}

Table 6 present data on the percentage of tissue water (extracellular plus intracellular) frozen after $3 \mathrm{~h}$ at $-20{ }^{\circ} \mathrm{C}$. In brown algae between 70 and $80 \%$ of tissue water was frozen after 3 h at $-20^{\circ} \mathrm{C}$. The red alga Dumontia incrassata exhibited a similar percentage of frozen water, whereas 50 to $60 \%$ of tissue water was frozen in other red algae. There was no apparent correlation between percentage of frozen water and treezing tolerance.

\section{Correlation between effect of freezing on} photosynthesis and plasma membrane permeability

An apparent correlation was observed between the freezing tolerance of the plasmalemma (assayed as apparent amino acid release following $3 \mathrm{~h}$ at $-20^{\circ} \mathrm{C}$ )
Table 6. Percentage of tissue water frozen in several different intertidal brown and red macroalgae after $3 \mathrm{~h}$ at $-20^{\circ} \mathrm{C}$. Values in parentheses are standard deviation of mean $(n=3)$. There were no significant differences in the percentage of frozen water between species

\begin{tabular}{|ll|}
\hline Species & Frozen (\%) \\
\hline Sub-littoral fringe/rock pool & \\
Dumontia incrassata & $81.2(13.1)$ \\
Chordaria flagelliformis & $73.3(2.72)$ \\
Laminaria digitata & $78.2(13.1)$ \\
Alaria esculenta & $82.2(7.67)$ \\
Fucus distichus & $71.6(6.73)$ \\
Lower-eulittoral & \\
Chondrus crispus & $59.1(14.5)$ \\
Palmaria palmata & $51.4(12.1)$ \\
Upper-eulittoral & \\
Mastocarpus stellatus & $56.6(13.1)$ \\
Fucus vesiculosus & $78.9(2.43)$ \\
\hline
\end{tabular}

and photosynthesis measured either $7 \mathrm{~d}$ after a single $12 \mathrm{~h}$ freezing event (Fig. $3 \mathrm{~A}$ ) or immediately after $3 \mathrm{~h}$ at $-20{ }^{\circ} \mathrm{C}$ (Fig. 3B). In both cases apparent amino acid release was higher in freezing susceptible than in freezing tolerent species.

\section{DISCUSSION}

The data presented in this paper support earlier observations that sub-littoral and rock pool algae are more susceptible to freezing damage than eulittoral 

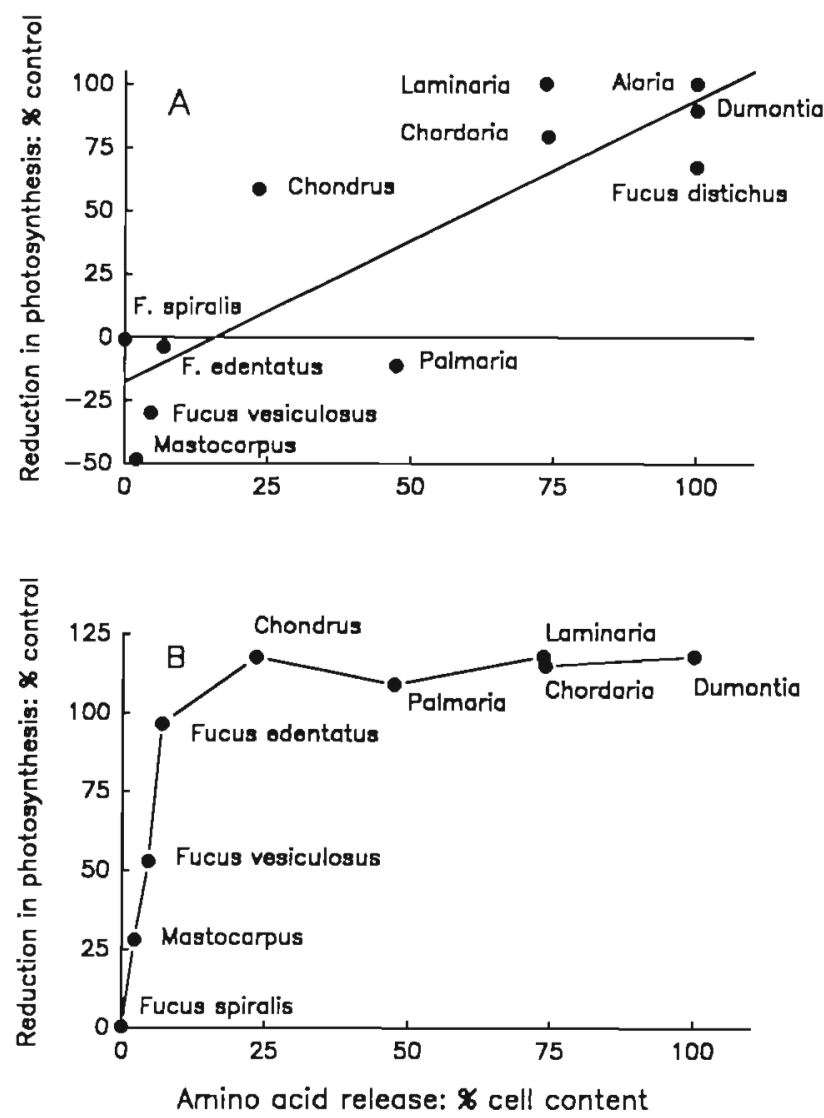

Fig. 3. Relationship between percentage cellular amino acid release following $3 \mathrm{~h}$ at $-20^{\circ} \mathrm{C}$ and $(\mathrm{A})$ photosynthesis measured $7 \mathrm{~d}$ after $12 \mathrm{~h}$ at $-20^{\circ} \mathrm{C}$, or (B) photosynthesis measured immediately after $3 \mathrm{~h}$ at $-20^{\circ} \mathrm{C}$ (see text for further details)

species (Biebl 1972, Frazer et al 1988). Exposure to a single 6 or $12 \mathrm{~h}$ freezing event was sufficient to inhibit photosynthesis in all sub-littoral fringe and rock pool species even after a 1 wh recovery period (Table 2). The inability to tolerate freezing may be 1 mechanism which excludes sub-littoral fringe and rock pools species from the eulittoral. This is supported by field observations in Maine, where Alaria and Laminaria spp. recruits colonize the low-intertidal every spring, survive and grow until winter when they are killed by the first severe frosts coincident with spring tides (unpubl. observations). Similar winter mortality of L. digitata associated with freezing temperatures has been reported previously (Todd \& Lewis 1984).

The low freezing tolerance of sub-littoral and rock pool seaweeds has long been established (see Biebl 1972). Thus, a more interesting question concerns the freezing tolerance of eulittoral species. Data presented in this paper suggest that a correlation may exist between freezing tolerance and vertical zonation of eulittoral algae analogous to that previously established for desiccation tolerance (Schonbeck \& Norton
1978, Dring \& Brown 1982). Although there was no significant differences between the response of most eulittoral algae to repeated freezing, photosynthesis was significantly more inhibited in Chondrus crispus (the most susceptible eulittoral species) than species from the upper-eulittoral (Table 3). Similarly, the only species in which photosynthesis was significantly more susceptible to daily freezing than Fucus vesiculosus (the least susceptible species), were $C$. crispus and Palmaria palmata from the lower-eulittoral (Table 3). A similar correlation between vertical zonation and freezing susceptibility was apparent in the ability of seaweeds to resume photosynthesis immediately after freezing (Table 4). For example, in the fucoids the percentage reduction increased from $0 \%$ in Fucus spiralis (which occurs highest on the shore) to 39 and 53 $\%$ in the upper-eulittoral Ascophyllum nodosum and $F$. vesiculosus, with $F$. edentatus from the lower-eulittoral experiencing a $97 \%$ reduction. These data suggest that freezing may operate as an important physiological stress, with reductions in photosynthesis and hence growth affecting competitive abilities. Species such as F. spiralis may have an advantage in the upper intertidal because of their ability to resume photosynthesis immediately following freezing and hence maximize photosynthesis during periods of immersion. This view is supported by the observation that repeated daily freezing reduces growth rates in the freezing susceptible $C$. crispus, but not in the freezing tolerant Mastocarpus stellatus (Dudgeon et al. unpubl.). The role of freezing as a physiological stress may be accentuated by the fact that photosynthesis is more severely affected than respiration (Tables 2 and 3).

The above discussion presupposes that inter-specific differences in freezing tolerance are genetic and not due to phenotypic acclimation, i.e. is the greater tolerance of Fucus spiralis due to genetic differences between this species and $F$. edentatus, or to phenotypic acclimation to the more frequent freezing experienced higher on the shore? This question is germane in view of reports of seasonal and vertical differences in freezing tolerance (Parker 1960, Bird \& McLachlan 1974), both of which are consistent with phenotypic acclimation. Laboratory experiments indicate that acclimation does occur in Chondrus crispus, with freezing tolerance increasing in response to moderate daily freezingexposure (Dudgeon et al. unpubl.). In contrast, freezing tolerance does not increase in Mastocarpus stellatus, which is inherently more freezing tolerant than $C$. crispus (Dudgeon et al. unpubl.). In view of the above, all that can be said at present is that freezing tolerance potentially contributes to observed zonation patterns. with more research being required on plants maintained under similar conditions to separate genetic and environmental components of freezing tolerance. 
On the basis of previous research with Chondrus crispus and Mastocarpus stellatus it was proposed that the plasmalemma played a major role in controlling freezing resistance (Dudgeon et al. 1989). This is consistent with the situation in higher plants (Lyons et al. 1979) and is supported by the relationship between apparent amino-acid release and freezing tolerance with freezing susceptible species releasing more amino acids than tolerant forms (Table 5; Fig. 3). Freezing appears to produce a breakdown of plasmalemma integrity, leading to a loss of cell contents on re-immersion. The majority of apparent amino acid release occurs within 5 min of re-immersion (Fig. 2). In eulittoral species, which lose less than $50 \%$ of total amino acids (Table 5), the cessation of release within $5 \mathrm{~min}$ suggests that membrane integrity is rapidly restored following re-immersion. In the case of sub-littoral fringe and rock pool species, the absence of additional release after $5 \mathrm{~min}$ is probably due to the complete loss of all free amino acids within this time, rather than recovery of the plasmalemma (Table 5).

The data in Fig. 3 suggest that the freezing stability of the plasmalemma can be used as an indicator of the freezing tolerance of seaweeds. This assumption is implicit in the work of Frazer et al. (1988), although these workers did not attempt to correlate plasmalemma breakdown with either survivorship or metabolic dysfunction. Frazer et al. (1988) used a conductivity technique developed for higher plants to assess freezing damage to the plasmalemma. However, this technique is destructive and also exposes plants to a second stress (immersion in deionized water) which may cause lysis and release of ions. The non-destructive amino acid technique described previously (Dudgeon et al. 1989) is preferable because it models natural re-immersion in sea water, and being non-destructive is suitable for long-term studies in which plants are repeatedly exposed to freezing.

Previous research on Chondrus crispus and Mastocarpus stellatus suggested that the degree of freezing damage may be correlated with the proportion of frozen water (Dudgeon et al. 1989). However, a larger data set (Table 6) indicates that no general correlation exists between freezing tolerance and percentage of tissue water frozen. Thus, freezing tolerance in intertidal seaweeds is not based on freezing avoidance, but rather on differences in the ability of species to tolerate the same conditions. In this respect freezing and desiccation tolerance are similar (Schonbeck \& Norton 1979b. Dromgoole 1980).

In summary, the data suggests that intertidal seaweeds exhibit a vertical gradient of freezing tolerance, with upper shore species being more tolerant than lower shore forms. The degree to which this reflects genetic adaptation or phenotypic acclimation was not investigated. although other studies suggest that both are important (Dudgeon et al. unpubl.). Plasmalemma stability plays a major role in freezing tolerance, with freezing susceptible species experiencing massive losses of cellular contents as a result of breakdown in membrane integrity.

Acknowledgements. The authors wish to express their sincere gratitude to Jane Podolak for her invaluable technical assistance without which this research would not have been possible. This research was supported by NSF grant OCE 8700763 .

\section{LITERATURE CITED}

Bauer, H., Kofler, R. (1987). Photosynthesis in frost-hardened and frost-stressed leaves of Hedera helix L. Pl. Cell Envir. 10: $339-346$

Biebl, R. (1970). Vergleichende Untersuchungen zur Temperaturresistenz von Meeralgen entlang der Pazifischen Küste Nordamerikas. Protoplasma 69: 61-83

Biebl, R. (1972). Temperature resistance of marine algae. Proc. 7th int. Seaweed Symp. (Sappora, Japan) 12: 23-28 [Nisizawa, K. (ed in chief) University Press, Tokyo]

Bird, C. J., McLachlan, J. (1974). Cold-hardiness of zygotes and embryos of Fucus (Fhaeophyceae, Fucales). Phycologia 13: 215-225

Chapman, A. R. O. (1986). Population and community ecology of seaweeds. Adv. mar. Biol. 23: 1-161

Connell, J. H. (1972), Community interactions on marine rocky intertidal shores. A. Rev. Ecol. Syst. 4: 169-192

Davison, I. R., Davison, J. O. (1987). The effect of growth temperature on enzyme activities in the brown alga Laminaria saccharina (L.) Lamour. Br. phycol. J. 22: 77-87

Delucia, E. H. (1987). The effect of freezing nights on photosynthesis, stomatal conductance and internal $\mathrm{CO}_{2}$ concentration in Engelmann spruce (Picea engelmannii Parry). Pl. Cell Envir 10: 333-338

Dring, M. J, Brown, F. A. (1982). Photosynthesis of intertidal brown algae during and after periods of emersion: a renewed search for physiological causes of zonation. Mar. Ecol. Prog. Ser. 8: 301-308

Dromgoole, F. I. (1980). Desiccation resistance of intertidal and subtidal algae. Botanica mar. 23: 149-159

Dudgeon, S. R., Davison, I. R., Vadas, R. L. (1989). Effect of freezing on photosynthesis of intertidal macroalgae: relative tolerance of Chondrus crispus and Mastocarpus stellatus (Rhodophyta). Mar. Biol. 101 107-114

Frazer, A. W J., Brown, M. T., Bannister, P. (1988). The frost resistance of some littoral and sub-littoral algae from southern New Zealand. Botanica mar. 31: 461-464

Grime, J. P. (1979). Plant strategies and vegetation processes. Wiley \& Sons, New York

Guiry, M. D., West, J., Kim, D. H., Masuda, M. (1984). Reinstatement of the genus Mastocarpus (Kutzing) Rhodophyta. Taxon 33: 53-63

Hanisak, M. D., Littler, M. M., Littler, D. S. (1988). Significance of macroalgal polymorphism. intraspecific tests of the functional-form model. Mar. Biol 99: 157-165

Hodgson, L. M. (1980). Control of the intertidal distribution of Gastrocionium coulteri in Monterey Bay, California, USA. Mar Biol. 57 121-126

Hutchinson, G. E. (1957). Concluding remarks. Cold Spring Harb. Symp. quant. Biol. 22: 415-422

Kanwisher, J. W. (1955). Freezung in intertidal animals. Biol. Buil. mar biol. Lab., Woods Hole 109: 56-63 
Kanwisher, J. W. (1957). Freezing and drying in intertidal algae. Biol. Bull. mar. biol. Lab., Woods Hole 113: 275-285

Lewis, J. R. (1964). The ecology of rocky shores. Hodder and Stoughton, London

Lubchenco, J. (1980). Algal zonation in the New England rocky intertidal community: an experimental analysis. Ecology 61: 333-334

Lyons, J. M. Graham, D., Raison, J. K. (1979). Low temperature stress in crop plants: the role of the membrane. Academic Press, New York

Oquist, G. (1983). Effects of low temperature on photosynthesis. Pl. Cell Envir. 6: 281-300

Parker, J. (1960). Seasonal changes in cold-hardiness of Fucus vesiculosus. Biol. Bull. mar. biol. Lab., Woods Hole 119: $474-478$

Provasoli, L. (1968). Media and prospects for the cultivation of marine algae. In: Watanabe, A., Hattori, A. (eds.) Cultures and collections of Algae. Jap. Soc. Plant. Physiol., p. 63-75

Rosen, H. (1957). A modified ninhydrin colorimetric analysis for amino acids. Archs. Biochem. Biophys. 67: 10-15

Schonbeck, M. W., Norton, T A. (1978). Factors controlling the upper limits of fucoid algae on the shore. J. exp. mar. Biol. Ecol. 31: 303-313

Schonbeck, M. W., Norton, T. A. (1979a). Drought-hardening in the upper-shore seaweeds Fucus spiralis and Pelvetia canaliculata. J. Ecol. 67: 687-696

This article was submitted to the editor
Schonbeck, M. W., Norton, T A. (1979b). An investigation of drought avoidance in intertidal fucoid algae. Botanica mar. 22: $133-144$

Schonbeck, M. W. Norton, T A. (1980a). The effects on intertidal fucoid algae of exposure to air under various conditions. Botanica mar. 23: 141-147

Schonbeck, M. W., Norton, T A. (1980b). Factors controlling the lower limits of fucoid algae on the shore. J. exp. mar. Biol. Ecol. 43: 131-150

South, G. R., Hooper, R. G. (1980). A catalogue and atlas of the benthic marine algae of the Island of Newfoundland. Mem. Univ. Newfoundland, Occ. Pap. Biol. 3: 136

Strand, M., Oquist, G. (1985). Inhibition of photosynthesis by freezing temperatures and high light levels in cold-acclimated seedlings of Scots pine (Pinus sylvestris). I. Effects on the light-limited and light-saturated rates of $\mathrm{CO}_{2}$ assimilation. Physiologia Pl. 64: 425-430

Todd, C. D., Lewis, J. R. (1984). Effects of low air temperature on Laminaria digitata in south-western Scotland. Mar. Ecol. Prog. Ser. 16: 199-201

Wilson, S. D., Keddy, P. A. (1986). Species competitive ability and position along a natural stress/disturbance gradient. Ecology 67: 1236-1242

Zaneveld, J. S. (1969). Factors controlling the delimitation of littoral benthic marine algal zonation. Am. Zool. 9: $367-391 \mathrm{R}$

Manuscript first received: April 6, 1989

Revised version accepted: August 7, 1989 